\title{
Systematic review of amifostine for the management of oral mucositis in cancer patients
}

\author{
Ourania Nicolatou-Galitis • Triantafyllia Sarri • Joanne Bowen • Mario Di Palma • \\ Vassilios E. Kouloulias • Pasquale Niscola • Dorothea Riesenbeck • Monique Stokman • \\ Wim Tissing • Eric Yeoh • Sharon Elad • Rajesh V. Lalla • For The Mucositis Study \\ Group of the Multinational Association of Supportive Care in Cancer/International Society of Oral Oncology \\ (MASCC/ISOO)
}

Received: 15 June 2012 / Accepted: 19 September 2012 /Published online: 3 October 2012

(C) Springer-Verlag Berlin Heidelberg 2012

\begin{abstract}
Purpose The aim of this study was to review the available literature from 1966 until December 31, 2010 and define clinical practice guidelines for the use of amifostine for the prevention and treatment of oral mucositis in cancer patients. Methods A systematic review was conducted by the Mucositis Study Group of the Multinational Association of Supportive Care in Cancer/International Society of Oral Oncology. The body of evidence for the use of amifostine, in each cancer treatment setting was assigned an evidence level. Based on the
\end{abstract}

O. Nicolatou-Galitis $(\bowtie) \cdot T$. Sarri

Dental Oncology Unit, Clinic of Hospital Dentistry, Dental School,

University of Athens,

Athens, Greece

e-mail: nicolatou.galitis@hotmail.com

J. Bowen $\cdot$ E. Yeoh

School of Medical Sciences, University of Adelaide,

Adelaide, South Australia, Australia

M. Di Palma

Ambulatory Department, Institut Gustave Roussy,

Villejuif, France

V. E. Kouloulias

2nd Department of Radiology, Medical School,

Attiko Hospital,

Athens, Greece

P. Niscola

Hematology Unit, St. Eugenio Hospital,

Rome, Italy

D. Riesenbeck

Radiation Oncology Practice,

Recklinghausen, Germany evidence level, one of the following three guideline determinations was possible: recommendation, suggestion, or no guideline possible.

Results Thirty papers were reviewed for evidence on amifostine as an intervention for oral mucositis. No guideline was possible for amifostine in any cancer treatment setting due to inadequate and conflicting evidence.

Conclusion Review of the amifostine studies for the prevention and treatment of oral mucositis has found insufficient evidence to support its use in any cancer treatment

\section{Stokman}

Department of Oral and Maxillofacial Surgery,

University Medical Center Groningen, University of Groningen,

Groningen, The Netherlands

W. Tissing

Department of Pediatric Oncology,

University Medical Center Groningen, University of Groningen,

Groningen, The Netherlands

E. Yeoh

Radiation Oncology Department, Royal Adelaide Hospital, Adelaide, Australia

S. Elad

Division of Oral Medicine, Eastman Institute for Oral Health, University of Rochester Medical Center,

Rochester, NY, USA

\section{R. V. Lalla}

Section of Oral Medicine and Neag Comprehensive

Cancer Center, University of Connecticut Health Center,

Farmington, CT, USA 
setting for this purpose. Additional well-designed research is needed to clarify the role of amifostine as an intervention for oral mucositis.

Keywords Amifostine - Guidelines · Systematic review · Oral mucositis

\section{Introduction}

Oral mucositis is a well-documented, frequent, dose-limiting complication of cancer therapy with adverse effects on tumor control, health care costs, and patient's quality of life. Complex biological inflammatory pathways are involved in the mucosal toxicity. Generation of oxidative stress and reactive oxygen species (ROS) by chemotherapeutic agents or radiation appears to be a primary event in most pathways leading to mucositis [1]. Amifostine (WR-1035, Ethyol ${ }^{\circledR}$ ) is an organic thiophosphate, which is thought to act as a free radical scavenger (anti-ROS) $[2,3]$. This might possibly prevent the up-regulation of inflammatory pathways related to cancer therapy toxicity and, thus, may allow compliance with the planned treatment regimens while preserving the patient's quality of life. Amifostine, administered intravenously, has been shown to reduce the incidence of acute and late xerostomia in head and neck cancer patients who receive radiotherapy, with or without chemotherapy [4-13]. The American Society of Clinical Oncology has recommended that the cytoprotective effect of amifostine "may be considered" for the prevention of cisplatin-associated nephrotoxicity, for the reduction of grade 3-4 neutropenia and to decrease acute and late xerostomia with fractionated radiotherapy for head and neck cancer $[14,15]$.

With regard to oral mucositis, the literature is conflicting with some studies suggesting amifostine to be beneficial in prevention of oral mucositis $[4,5,7,11,13,16-24]$ and some studies suggesting that amifostine does not reduce mucositis prevalence or severity $[6,8,10,25-31]$. Stokman et al. performed a meta-analysis of seven studies and reported a positive preventive effect of amifostine on severe oral mucositis [32]. A Cochrane meta-analysis of 11 studies concluded that there is only weak unreliable evidence that amifostine may prevent oral mucositis [33].

The Mucositis Study Group of the Multinational Association of Supportive Care in Cancer/International Society of Oral Oncology (MASCC/ISOO), based on the results of a systematic review of clinical literature between 1966 and 2002, did not recommend the use of amifostine for the prevention of oral mucositis, due to insufficient evidence to support any guideline [34]. No new convincing data were found during a second systematic review of the literature between 2002 and 2005 and, thus, no guideline was again possible on the use of amifostine in the prevention of oral mucositis $[35,36]$. As part of a comprehensive update of the
MASCC/ISOO clinical practice guidelines for mucositis, the aim of this study was to review all the available literature now extended to December 31, 2010 and define clinical practice guidelines for the use of amifostine for the prevention and treatment of oral mucositis in cancer patients.

\section{Methods}

The methods are described in detail in the papers by Bowen et al. and Elad et al. elsewhere in this issue. Briefly, a literature search for relevant articles indexed in Medline between 1966 and December 31, 2010 was conducted. Articles that evaluated amifostine for the prevention and/or treatment of cancer therapy-induced oral mucositis in humans were selected for review. The detailed inclusion and exclusion criteria are presented in this section. Each paper was reviewed by two independent reviewers. The large number of papers was divided among 12 calibrated reviewers to keep the workload reasonable.

Data were extracted using a standard electronic form. Studies were scored for their level of evidence based on the Somerfield criteria [37], and flaws were listed according to the Hadorn criteria [38]. A well-designed study was defined as a study with no major flaws per the Hadorn criteria. Findings from the reviewed studies were integrated into guidelines based on the overall level of evidence for each intervention. Guidelines were classified into three types: recommendation, suggestion, and no guideline possible.

Guidelines were separated based on (1) the aim of the intervention (prevention or treatment of mucositis); (2) the treatment modality (radiotherapy, chemotherapy, chemoradiotherapy, or high-dose conditioning therapy for hematopoietic stem cell transplant), and (3) the route of administration of the intervention.

Studies relevant to management of radiation- and/or chemotherapy-induced oral mucositis using anti-inflammatory interventions including amifostine were reviewed. The results of the reviews related to other anti-inflammatory agents are described and discussed thoroughly in a separate article. The current article presents the results for studies investigating amifostine as an intervention for oral mucositis.

\section{Results}

The intervention keywords used for the literature search of this section (anti-inflammatory agents) were as follows: Aminosalicylic acid, Amifostine, Amlexanox, Anti-inflammatory, Anti-TNF, Anti-tumor necrosis factor, Aspirin, Benadryl, Benzydamine, Betamethasone, Celecoxib, Corticosteroid, Dexamethasone, Diphenhydramine, Ethyol, Flurbiprofen, Histamine, Hydrocortisone, Ibuprofen, Indomethacin, Infliximab, 
Irsogladine, Lactoferrin, Mesalazine, Misoprostol, $N$-Acetyl cysteine, Non-steroidal anti-inflammatory agents, NSAIDS, Orgotein, Prednisone, Prostaglandin, RK-02-02, Salicylic acid, Steroid, Thalidomide, TNF antibody, TNF inhibitor, and Tumor necrosis factor/TNF. The literature searches identified 908 articles. Of those, 759 papers were excluded after evaluating title and/or abstract by using Endnote X5 bibliography software. Articles that did not report the effects of an intervention on mucositis or on related outcomes, animal or in vitro studies, and articles published in a language other than English were excluded. Forty-three review articles were further excluded after detailed evaluation of their title and/or abstract. The remaining 106 articles, related to anti-inflammatory agents $(n=66)$ or to amifostine $(n=40)$ were assessed in detail for methodological quality. Finally, 30 eligible articles investigated amifostine specifically as the intervention agent for the prevention of oral mucositis and were selected for this review. The selected literature was divided by route of administration of amifostine (intravenous, subcutaneous, and local application) and by type of cancer therapy (head and neck radiotherapy, head and neck chemoradiotherapy, high-dose chemotherapy, and standard dose chemotherapy).

\section{Intravenous administration}

\section{Head and neck radiotherapy: prevention}

In patients undergoing radiotherapy for head and neck cancer, five articles were reviewed $[6,10,13,16,21]$. In all five studies, amifostine was administered for prevention. Three studies reported that amifostine reduced the severity and/or the duration of oral mucositis $[13,16$, 21]. One of these three studies was a retrospective record review. [21]. Placebo was not used in the control group, and the double-blinded method was not followed in the other two studies $[13,16]$. Furthermore, in one study, side effects of amifostine (150 mg/m $\mathrm{m}^{2}$ twice daily) led to definitive interruption of amifostine use in five out of 13 patients, making the evaluation of the effect of amifostine difficult [16]. Amifostine did not ameliorate oral mucositis in two studies $[6,10]$. The mode of randomization was not clear in one, while both studies did not use placebo in the control group and did not follow the double-blinded method. The mixed results from these five studies as well as the Hadorn major flaws such as the lack of placebo use and double blinding did not allow for a recommendation or suggestion for or against the use of amifostine in the prevention of oral mucositis. Thus, no guidelines were possible.

\section{Head and neck chemoradiotherapy: prevention}

In patients undergoing chemoradiotherapy for head and neck cancer, eight articles were reviewed $[4,5,7,9,11$,
29, 30, 39 ]. In all eight studies, amifostine was administered for prevention. The severity of oral mucositis was significantly reduced in three prospective, randomized studies $[4,5,7]$. All three studies were not, however, blinded and did not use the placebo-controlled method. Furthermore, the diagnostic criteria for oral mucositis were not adequately described. The infusion of $250 \mathrm{mg}$ of amifostine $15 \mathrm{~min}$ prior to radiotherapy reduced the severity of oral mucositis in the experimental when compared to the control group, but the difference did not reach significant levels in one, non-blinded, non-placebo-controlled study [9]. Grade 3 oral mucositis was reduced when compared to historical controls (40 versus $70 \%$ ) in patients who received $500 \mathrm{mg}$ amifostine within $1 \mathrm{~h}$ before radiotherapy [11]. Oral mucositis was significantly lower in severity at all 10 Gy increments except 60 Gy and over in patients who received $300 \mathrm{mg}$ amifostine before radiotherapy when compared with historical controls [39]. On the other hand, no significant benefit of the addition of amifostine in head and neck cancer chemoradiotherapy was reported in two studies [29, 30]. One of those two studies used historical controls [29]. In a multiinstitutional, randomized, double-blinded, and placebocontrolled study, the incidence of grade 3 or higher acute mucositis was greater (39\%) in the amifostine group as compared to $22 \%$ in the placebo group $(p=0.055)$ [30]. Due to the conflicting results of the studies evaluated above and the different Hadorn major flaws, such as the lack of blinding and placebo controls and the use of historical controls, no guideline could be established for the use of amifostine to prevent oral mucositis in patients receiving chemoradiotherapy for head and neck cancers.

\section{High-dose chemotherapy: prevention}

In patients with hematological malignancies or advanced solid cancers, who received amifostine $\left(680-910 \mathrm{mg} / \mathrm{m}^{2}\right)$ prior to high-dose chemotherapy and peripheral blood stem cell or bone marrow transplantation, nine articles were reviewed $[17,19,20,22,23,25-27,40]$. Of those, three articles included total body irradiation in the conditioning regimen [22, 27 , 40]. Five studies reported a beneficial effect for the use of amifostine [17, 19, 20, 22, 23]. One study showed a statistically significant reduction of duration of oral mucositis of all grades, but no differences in the incidence or duration of severe (grade 3 or 4 ) oral mucositis [40]. Three studies reported no improvement of oral mucositis with amifostine [25-27]. Of these nine studies, three were prospective but not blinded or placebo-controlled, and only two were randomized $[19,23]$. Historical controls were used in six studies [17, 22, 25-27, 40 ]. The inconsistent results and the Hadorn major flaws of these studies, such as the lack of blinding and placebo controls and the use of historical controls, did not allow for any guideline for or against the use of amifostine. 


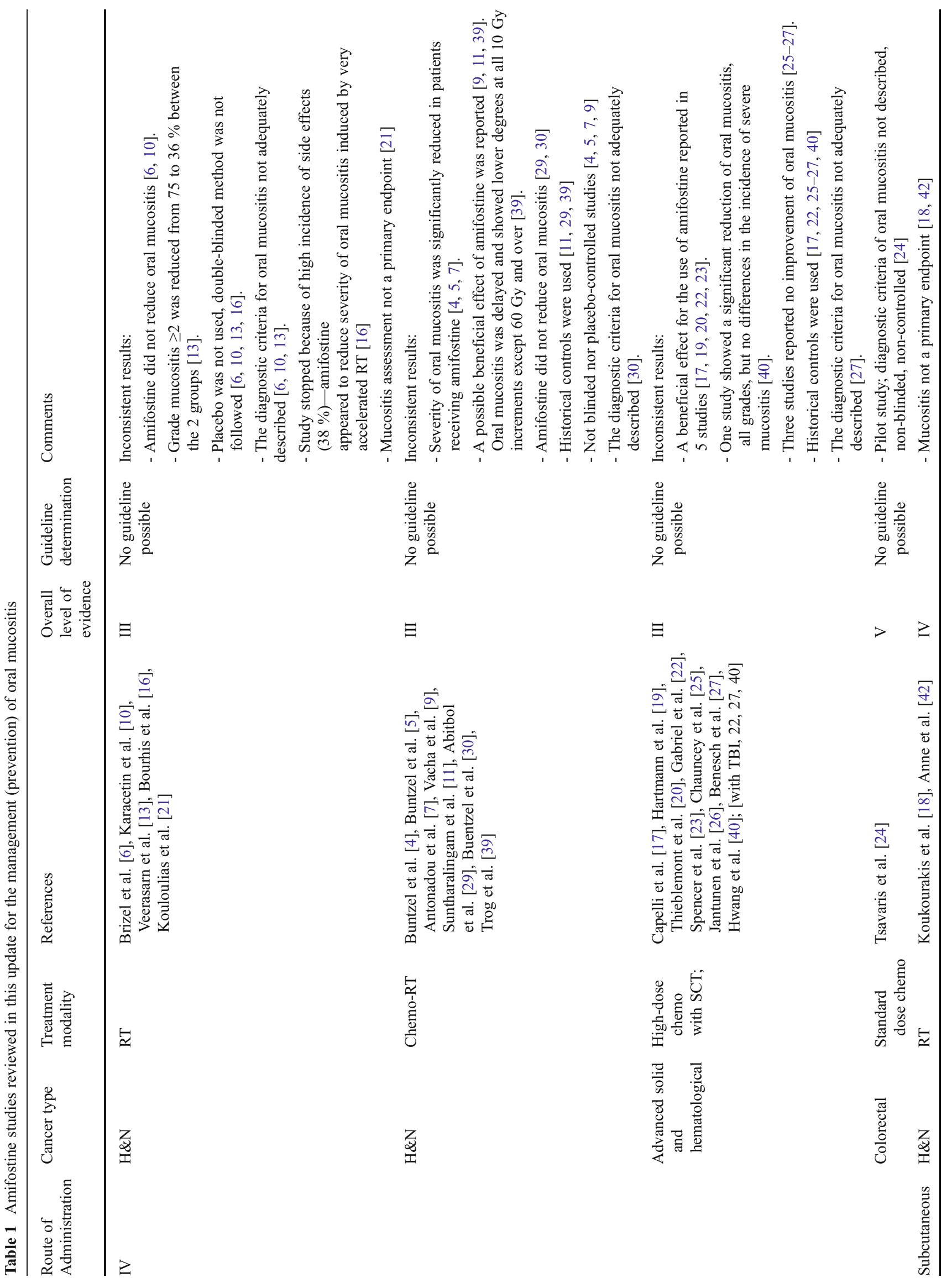


Amifostine, in a reduced dose $\left(500 \mathrm{mg} / \mathrm{m}^{2}\right)$, protected against severe diarrhea; it was associated with weekly administration of fluorouracil (5-FU) and folinic acid in advanced colorectal cancer [24]. Improvement of mucositis was also reported. This was a non-controlled, non-blinded, before-and-after, pilot study. It was not clear whether oral mucositis was assessed and graded during the study. These factors did not allow for any guideline to be developed for the use of amifostine to prevent oral mucositis associated with standard dose chemotherapy.

Subcutaneous administration

The subcutaneous route of administration of amifostine is simpler and saves time compared with the intravenous route of administration. It may also be associated with a lower incidence of side effects such as hypotension. Subcutaneous administration has been tested for the prevention of oral mucositis in head and neck cancer patients, who received radiotherapy or chemoradiotherapy. A total of six articles were reviewed [18, 31, 41-44].

\section{Radiotherapy alone: prevention}

Two articles were reviewed [18, 42]. A significantly reduced severity of symptoms related to oral mucosa was reported in the first, randomized, but neither blinded nor placebocontrolled study [18]. No conclusion on oral mucositis was reached in the second, non-controlled study, which described the treatment-related toxicity during the course of radiotherapy. Oral mucositis was recorded as one of the amifostinerelated side effects [42]. Insufficient evidence and Hadorn major flaws, such as the lack of placebo use and the nonblinded method, of both studies did not allow for any recommendation or suggestion for the use of amifostine in this setting.

\section{Chemoradiotherapy: prevention}

Four articles were reviewed [31, 41, 43, 44]. The rate of oral mucositis was not improved with amifostine in one randomized but neither blinded nor placebo-controlled study [31]. The other three studies tested the feasibility of the use of subcutaneous amifostine [41, 43, 44]. One of them combined 26 patients who received chemoradiotherapy with seven patients, who received radiotherapy alone [41]. Treatmentrelated toxicity was described in all three studies, but due to the lack of control subjects, no conclusion on the effect of amifostine on oral mucositis could be drawn in either study. A lower, though not significantly different, incidence of severe mucositis in patients who received doses of amifostine equal 
or greater than $750 \mathrm{mg} / \mathrm{m}^{2}$ when compared to those who received lower doses was reported in one study [44]. Oral mucositis rates were found to be similar to those reported in trials with i.v. amifostine [43]. Due to the inconsistent results and insufficient evidence and the Hadorn major flaws of the studies, such as the lack of placebo use and the non-blinded method, no guideline was possible on the use of subcutaneous amifostine in the prevention of oral mucositis in head and neck cancer patients, who receive radiotherapy or chemoradiotherapy.

\section{Local application: prevention}

One prospective, neither blinded nor placebo-controlled, study tested amifostine mouthwash $(10 \mathrm{ml}, 20 \mathrm{mg} / \mathrm{mL})$ for the prevention of epirubicin-induced oral mucositis [28]. Local application was feasible. A significant negative correlation was found between amifostine (WR-1065) concentration in mouth mucosa cells and the OMAS mucositis score, meaning that a higher cellular concentration of WR1065 was correlated with less mucositis. No clinical benefit was, however, detected at the amifostine dose used. No guideline was possible regarding the use of amifostine in this setting due to the Hadorn major flaws of the study.

The results of the literature review for the use of amifostine in the prevention of oral mucositis are summarized in Table 1. No article tested amifostine for the treatment of oral mucositis in any cancer setting.

\section{Discussion}

The present systematic review of the clinical literature on the use of amifostine for the prevention and treatment of oral mucositis in different cancer settings included 30 articles, selected based on defined criteria and published from 1966 until December 31, 2010. All 30 articles used amifostine to prevent oral mucositis. Six articles were published between 2006 and 2010, following the last systematic review by the Mucositis Study Group of MASCC/ISOO [35]. In our review, we could not demonstrate any evidence to support the use of amifostine for the prevention or the treatment of oral mucositis in any cancer setting. Amifostine, according to 16 articles, may reduce the severity of oral mucositis in cancer therapy. No benefit of the amifostine use was reported in ten and no conclusion could be drawn in four articles. In addition to the major flaws encountered in the studies, differences in the time of administration, dose of amifostine, cancer therapy intensity, and mode of cancer therapy, and possibly other factors, including the complex pathophysiology of mucosal injury, could be related to the inconsistent and conflicting results.

Points that could be considered in the future and could be included in well-designed studies are the time of amifostine infusion prior to radiotherapy, adequate dose of amifostine for adequate exposure and increased cytoprotection, cancer therapy intensity, cancer modality, such as the allogeneic stem cell transplantation, which includes the potential development of GvHD versus autologous stem cell transplantation, and the complex pathophysiology of mucosal injury. Amifostine could be of interest either alone or as part of a combined preventive therapy strategy.

In conclusion, conflicting results, insufficient data, and Hadorn major flaws, including the retrospective nature of some of the studies, the use of historical controls, or the lack of controls, the lack of proper randomization of the study subjects, the lack of placebo-controlled and double-blinded methods, did not allow any guideline related to the use of amifostine in the prevention of oral mucositis in the present review. The efficacy of amifostine in the prevention of oral mucositis should be evaluated in new, well-designed, sufficiently powered, randomized, controlled trials. Their results will form the basis for future guidelines.

Disclosures The Mucositis Guidelines Update was sponsored by Helsinn Healthcare S.A., Switzerland and BioAlliance Pharma, France. Per MASCC policy, no industry representatives had any role in the development of the guidelines.

\section{References}

1. Sonis ST, Elting LS, Keefe D, Peterson DE, Schubert M, HauerJensen M, Bekele BN, Raber-Durlacher J, Donnelly JP, Rubenstein EB (2004) Perspectives on cancer therapy-induced mucosal injury: pathogenesis, measurement, epidemiology, and consequences for patients. Cancer 100(9 Suppl):1995-2025

2. Capizzi RL (1999) The preclinical basis for broad-spectrum selective cytoprotection of normal tissues from cytotoxic therapies by amifostine. Semin Oncol 26(2 Suppl 7):3-21

3. Santini V (2001) Amifostine: chemotherapeutic and radiotherapeutic protective effects. Expert Opin Pharmacother 2:479-489

4. Buntzel J, Kuttner K, Frohlich D, Glatzel M (1998) Selective cytoprotection with amifostine in concurrent radiochemotherapy for head and neck cancer. Ann Oncol 9:505-509

5. Buntzel J, Schuth J, Kuttner K, Glatzel M (1998) Radiochemotherapy with amifostine cytoprotection for head and neck cancer. Support Care Cancer 6:155-160

6. Brizel DM, Wasserman TH, Henke M, Strnad V, Rudat V, Monnier A, Eschwege F, Zhang J, Russell L, Oster W, Sauer R (2000) Phase III randomized trial of amifostine as a radioprotector in head and neck cancer. J Clin Oncol 18:3339-3345

7. Antonadou D, Pepelassi M, Synodinou M, Puglisi M, Throuvalas N (2002) Prophylactic use of amifostine to prevent radiochemotherapyinduced mucositis and xerostomia in head-and-neck cancer. Int $\mathrm{J}$ Radiat Oncol Biol Phys 52:739-747

8. Nicolatou-Galitis O, Sotiropoulou-Lontou A, Velegraki A, Pissakas G, Kolitsi G, Kyprianou K, Kouloulias V, Papanikolaou I, Yiotakis I, Dardoufas K (2003) Oral candidiasis in head and neck cancer patients receiving radiotherapy with amifostine cytoprotection. Oral Oncol 39:397-401

9. Vacha P, Fehlauer F, Mahlmann B, Marx M, Hinke A, Sommer K, Richter E, Feyerabend T (2003) Randomized phase III trial of 
postoperative radiochemotherapy $+/-$ amifostine in head and neck cancer. Is there evidence for radioprotection? Strahlentherapie und Onkologie: Organ der Deutschen Rontgengesellschaft 179:385-389

10. Karacetin D, Yucel B, Leblebicioglu B, Aksakal O, Maral O, Incekara $\mathrm{O}$ (2004) A randomized trial of amifostine as radioprotector in the radiotherapy of head and neck cancer. J BUON 9:23-26

11. Suntharalingam M, Jaboin J, Taylor R, Wolf J, Banglore M, Van Echo D, Ord R (2004) The evaluation of amifostine for mucosal protection in patients with advanced loco-regional squamous cell carcinomas of the head and neck (SCCHN) treated with concurrent weekly carboplatin, paclitaxel, and daily radiotherapy (RT). Semin Oncol 31(6 Suppl 18):2-7

12. Wasserman TH, Brizel DM, Henke M, Monnier A, Eschwege F, Sauer R, Strnad V (2005) Influence of intravenous amifostine on xerostomia, tumor control, and survival after radiotherapy for head-and-neck cancer: 2-year follow-up of a prospective, randomized, phase III trial. Int J Radiat Oncol Biol Phys 63:985-990

13. Veerasarn V, Phromratanapongse P, Suntornpong N, Lorvidhaya V, Sukthomya V, Chitapanarux I, Tesavibul C, Swangsilpa T, Khorprasert C, Shotelersuk K, Kongthanarat Y, Panichevaluk A, Chiewvit S, Pusuwan P, Aekmahachai M, Ratchadara S, Sirilipoche S, Saengsuda Y (2006) Effect of Amifostine to prevent radiotherapyinduced acute and late toxicity in head and neck cancer patients who had normal or mild impaired salivary gland function. J Medic AssThail Chotmaihet thangphaet 89:2056-2067

14. Schuchter LM, Hensley ML, Meropol NJ, Winer EP (2002) 2002 update of recommendations for the use of chemotherapy and radiotherapy protectants: clinical practice guidelines of the American Society of Clinical Oncology. J Clinic Oncol 20:2895-2903

15. Hensley ML, Hagerty KL, Kewalramani T, Green DM, Meropol NJ, Wasserman TH, Cohen GI, Emami B, Gradishar WJ, Mitchell RB, Thigpen JT, Trotti A 3rd, von Hoff D, Schuchter LM (2009) American Society of Clinical Oncology 2008 clinical practice guideline update: use of chemotherapy and radiation therapy protectants. J Clinical Oncol 27:127-145

16. Bourhis J, De Crevoisier R, Abdulkarim B, Deutsch E, Lusinchi A, Luboinski B, Wibault P, Eschwege F (2000) A randomized study of very accelerated radiotherapy with and without amifostine in head and neck squamous cell carcinoma. Int J Radiat Oncol Biol Phys 46:1105-1108

17. Capelli D, Santini G, De Souza C, Poloni A, Marino G, Montanari M, Lucesole M, Brunori M, Massidda D, Offidani M, Leoni P, Olivieri A (2000) Amifostine can reduce mucosal damage after high-dose melphalan conditioning for peripheral blood progenitor cellautotransplant: a retrospective study. Brit J Haem 110:300-307

18. Koukourakis MI, Kyrias G, Kakolyris S, Kouroussis C, Frangiadaki C, Giatromanolaki A, Retalis G, Georgoulias V (2000) Subcutaneous administration of amifostine during fractionated radiotherapy: a randomized phase II study. J Clinic Oncol 18:2226-2233

19. Hartmann JT, von Vangerow A, Fels LM, Knop S, Stolte H, Kanz L, Bokemeyer C (2001) A randomized trial of amifostine in patients with high-dose VIC chemotherapy plus autologous blood stem cell transplantation. Brit J Cancer 84:313-320

20. Thieblemont C, Dumontet C, Saad H, Roch N, Bouafia F, Arnaud P, Hequet O, Espinouse D, Salles G, Roy P, Eljaafari-Corbin A, Du Manoir-Baumgarten C, Coiffier B (2002) Amifostine reduces mucosal damage after high-dose melphalan conditioning and autologous peripheral blood progenitor cell transplantation for patients with multiple myeloma. Bone Marrow Transplant 30:769-775

21. Kouloulias VE, Kouvaris JR, Kokakis JD, Kostakopoulos A, Mallas E, Metafa A, Vlahos LJ (2004) Impact on cytoprotective efficacy of intermediate interval between amifostine administration and radiotherapy: a retrospective analysis. Int J Radiat Oncol Biol Phys 59:1148-1156

22. Gabriel DA, Shea TC, Serody JS, Moore DT, Kirby SL, Harvey D, Krasnov C (2005) Cytoprotection by amifostine during autologous stem cell transplantation for advanced refractory hematologic malignancies. Biol Blood Marrow Transplant 11:1022-1030

23. Spencer A, Horvath N, Gibson J, Prince HM, Herrmann R, Bashford J, Joske D, Grigg A, McKendrick J, Prosser I, Lowenthal R, Deveridge S, Taylor K (2005) Prospective randomised trial of amifostine cytoprotection in myeloma patients undergoing highdose melphalan conditioned autologous stem cell transplantation. Bone Marrow Transplant 35:971-977

24. Tsavaris N, Kosmas C, Vadiaka M, Zonios D, Papalambros E, Papantoniou N, Margaris H, Zografos G, Rokana S, Retalis G, Koufos C (2003) Amifostine, in a reduced dose, protects against severe diarrhoea associated with weekly fluorouracil and folinic acid chemotherapy in advanced colorectal cancer: A pilot study. JPain Symptom Manage 26:849-854

25. Chauncey TR, Gooley TA, Lloid ME, Schubert MM, Lilleby K, Holmberg L, Bensinger WI (2000) Pilot trial of cytoprotection with amifostine given with high-dose chemotherapy and autologous peripheral blood stem cell transplantation. Amer J Clinic Oncol 23:406-411

26. Jantunen E, Kuittinen T, Nousiainen T (2002) A pilot study on feasibility and efficacy of amifostine preceding high-dose melphalan with autologous stem cell support in myeloma patients. Leuk Lymphoma 43:1961-1965

27. Benesch M, McDonald GB, Schubert M, Appelbaum FR, Deeg HJ (2003) Lack of cytoprotective effect of amifostine following HLAidentical sibling transplantation for advanced myelodysplastic syndrome (MDS): a pilot study. Bone Marrow Transplant 32:1071-1075

28. Stokman MA, Wachters FM, Koopmans P, Burgerhof JG, Groen HJ, Spijkervet FK, Uges DR, Hospers GA (2004) Outcome of local application of amifostine (WR-1065) on epirubicin-induced oral mucositis. A phase II study. Anticancer Res 24(5B):3263-3267

29. Abitbol A, Abdel-Wahab M, Harvey M, Lewin A, Troner M, Hamilton-Nelson K, Wu J, Markoe A (2005) Phase II study of tolerance and efficacy of hyperfractionated radiation therapy and 5-fluorouracil, cisplatin, and paclitaxel (taxol) and amifostine (ethyol) in head and neck squamous cell carcinomas: A-3 protocol. Amer J Clinic Oncol 28:449-455

30. Buentzel J, Micke O, Adamietz IA, Monnier A, Glatzel M, de Vries A (2006) Intravenous amifostine during chemoradiotherapy for head-and-neck cancer: a randomized placebo-controlled phase III study. Int J Radiat Oncol Biol Phys 64:684-691

31. Haddad R, Sonis S, Posner M, Wirth L, Costello R, Braschayko P, Allen A, Mahadevan A, Flynn J, Burke E, Li Y, Tishler RB (2009) Randomized phase 2 study of concomitant chemoradiotherapy using weekly carboplatin/paclitaxel with or without daily subcutaneous amifostine in patients with locally advanced head and neck cancer. Cancer 115:4514-4523

32. Stokman MA, Spijkervet FK, Boezen HM, Schouten JP, Roodenburg JL, de Vries EG (2006) Preventive intervention possibilities in radiotherapy- and chemotherapy-induced oral mucositis: results of meta-analyses. J Dent Res 85:690-700

33. Worthington HV, Clarkson JE, Bryan G, Furness S, Glenny AM, Littlewood A, McCabe MG, Meyer S, Khalid T (2010) Interventions for preventing oral mucositis for patients with cancer receiving treatment. Cochrane Database Syst Rev (12):CD000978

34. Rubenstein EB, Peterson DE, Schubert M, Keefe D, McGuire D, Epstein J, Elting LS, Fox PC, Cooksley C, Sonis ST (2004) Clinical practice guidelines for the prevention and treatment of cancer therapy-induced oral and gastrointestinal mucositis. Cancer 100(9 Suppl):2026-2046

35. Bensadoun RJ, Schubert MM, Lalla RV, Keefe D (2006) Amifostine in the management of radiation-induced and chemo-induced mucositis. Support Care Cancer 14:566-572

36. Keefe DM, Schubert MM, Elting LS, Sonis ST, Epstein JB, RaberDurlacher JE, Migliorati CA, McGuire DB, Hutchins RD, Peterson DE (2007) Updated clinical practice guidelines for the prevention and treatment of mucositis. Cancer 109:820-831 
37. Somerfield MR, McCrae RR (2000) Stress and coping research. Methodological challenges, theoretical advances, and clinical applications. Amer Psychol 55:620-625

38. Hadorn DC, Baker D, Hodges JS, Hicks N (1996) Rating the quality of evidence for clinical practice guidelines. J Clinic Epidem 49:749-754

39. Trog D, Bank P, Wendt TG, Koscielny S, Beleites E (1999) Daily amifostine given concomitantly to chemoradiation in head and neck cancer. A pilot study. Strahlentherapie und Onkologie: Organ der Deutschen Rontgengesellschaft 175:444-449

40. Hwang WY, Koh LP, Ng HJ, Tan PH, Chuah CT, Fook SC, Chow H, Tan KW, Wong C, Tan CH, Goh YT (2004) A randomized trial of amifostine as a cytoprotectant for patients receiving myeloablative therapy for allogeneic hematopoietic stem cell transplantation. Bone Marrow Transplant 34:51-56

41. Ozsahin M, Betz M, Matzinger O, Bron L, Luthi F, Pasche P, Azria D, Mirimanoff RO, Zouhair A (2006) Feasibility and efficacy of subcutaneous amifostine therapy in patients with head and neck cancer treated with curative accelerated concomitant-boost radiation therapy. Arch Otolaryn Head Neck Surg 132:141-145

42. Anne PR, Machtay M, Rosenthal DI, Brizel DM, Morrison WH, Irwin DH, Chougule PB, Estopinal NC, Berson A, Curran WJ Jr (2007) A Phase II trial of subcutaneous amifostine and radiation therapy in patients with head-and-neck cancer. Int $\mathrm{J}$ Radiat Oncol Biol Phys 67:445-452

43. Law A, Kennedy T, Pellitteri P, Wood C, Christie D, Yumen O (2007) Efficacy and safety of subcutaneous amifostine in minimizing radiation-induced toxicities in patients receiving combinedmodality treatment for squamous cell carcinoma of the head and neck. Int J Radiat Oncol Biol Phys 69:1361-1368

44. Koukourakis MI, Tsoutsou PG, Karpouzis A, Tsiarkatsi M, Karapantzos I, Daniilidis V, Kouskoukis C (2010) Radiochemotherapy with cetuximab, cisplatin, and amifostine for locally advanced head and neck cancer: a feasibility study. Int J Radiat Oncol Biol Phys 77:9-15 